\title{
Rapeseed meal as an alternative protein source in the diet of GIFT tilapia cultured in cages in reservoir
}

\author{
AUROBINDA UPADHYAY ${ }^{1}$, N. FELIX ${ }^{2}$ AND E. PRABU ${ }^{3 *}$ \\ ${ }^{1}$ Fisheries College and Research Institute, Tamil Nadu Dr. J. Jayalalitha Fisheries University, Thoothukudi - 628008 \\ Tamil Nadu, India \\ ${ }^{2}$ Directorate of Incubation and Vocational Training in Aquaculture, Tamil Nadu Dr. J. Jayalalitha Fisheries University \\ ECR Muttukadu, Chennai - 603 112, Tamil Nadu, India \\ ${ }^{3}$ Dr. M. G. R. Fisheries College and Research Institute, Ponneri - 601 204, Tamil Nadu, India \\ e-mail:prabufcri@gmail.com
}

\section{ABSTRACT}

\begin{abstract}
Evaluation of the efficiency of rapeseed meal (RSM) as an alternative protein source by replacing soybean meal (SBM) in the diets of GIFT strain of Nile tilapia Oreochromis niloticus was carried out in cages installed at Poondi Reservoir, Tamil $\mathrm{Nadu}$, South India. Five isonitrogenous (30\% protein) and isolipidic (7\% lipid) diets were formulated by incorporating RSM protein by replacing SBM at 0 (control diet), 25, 50, 75 and 100\% levels (0RSM, 25RSM, 50RSM, 75RSM and 100RSM). Each diet was fed to two replicate groups of GIFT tilapia with a mean initial weight of $20.38 \pm 0.07 \mathrm{~g}$ for 60 days in cages. GIFT tilapia fishes fed with 75RSM diet attained maximum percentage weight gain (PWG 590.89 \%), maximum specific growth rate (SGR 3.22), best feed conversion ratio (FCR 1.03) and maximum protein efficiency ratio (PER 3.23) among the treatments. The fishes fed with 0RSM, 50RSM and 100RSM diets showed no significant difference $(\mathrm{p}>0.05)$ in mean weight gain (MWG), SGR, FCR and PER. No significant difference in hepatosomatic index (HSI) was found among the fishes fed with 0RSM, 75RSM and 100RSM diets. There was no significant difference ( $>0.05$ ) observed in survival between treatments. The whole body proximate composition (moisture, protein, lipid and ash) of GIFT tilapia did not differ significantly $(\mathrm{p}>0.05)$ among the treatments. It was concluded that, rapeseed meal can completely $(100 \%)$ replace soybean meal protein in the diets of cage cultured GIFT tilapia in reservoir, without compromising growth, FCR and whole body composition.
\end{abstract}

Keywords: Cages, DL-methionine, GIFT tilapia, Rapeseed meal, Soybean meal, Survival

\section{Introduction}

World inland aquaculture presently contributes 51.4 million t (2016) of fish annually and finfish farming still dominates inland aquaculture, accounting for 92.5\% (47.5 million $\mathrm{t}$ ) of total production from inland aquaculture (FAO, 2018). Though various culture practices are available, freshwater aquaculture in India mainly depends on pond-based systems. Considering the ever increasing and ever conflicting cross-sectoral demands for water and land, there are limitations for growth in pond based aquaculture. Culture of fish in enclosures such as cages and pens installed in open water bodies offer scope for increasing production obviating the need for more land based fish farms.

A well documented effort in tilapia genetic improvement is the development of genetically improved farmed tilapia (GIFT), in Asia by the World Fish Centre (Ponzoni, 2008). The line was developed by crossing eight strains of $O$. niloticus followed by combined family and mass selection for body weight. Field trials demonstrated that the first generation GIFT tilapia line yielded $18-58 \%$ larger fish compared with local strains of $O$. niloticus. The coefficient of variation (CV) for harvest weight in GIFT or Nile tilapia in general is around 40 to $60 \%$ (Ponzoni et al., 2005; Nguyen et al., 2007; Khaw et al., 2010), which is considered large. GIFT tilapia is known to be a fast growing strain of $O$. niloticus, which is widely used in a variety of culture systems in Asia (Dey et. al., 2000). $\mathrm{Ng}$ and Hanim (2007) reported that growth was influenced by the interaction between diet and tilapia genotype and feed conversion ratios were 14 and $33 \%$ better in GIFT tilapia compared to red tilapia fed 25 or $35 \%$ protein diets respectively. Promoting GIFT tilapia culture can have enormous benefits for the growing aquaculture industry of world's top most fish producing countries like India.

Soybean meal (SBM) is a widely available protein source with nearly sufficient digestible protein, high energy content, good amino acid profile (Hertrampf and Piedadu-Pascual, 2012) and used as a cost effective feed ingredient to replace fish meal in aquafeeds (Yue and Zhou, 2008). Increase in the use of SBM results in steady increase in its cost. Rapeseed meal (RSM) is a major 
protein source (a little less than $40 \%$ protein), that can be used as a feed ingredient for livestock, poultry and fishes. RSM is relatively less costly than soybean meal and the amino acid content of RSM is comparable e with that of SBM and richer in methionine (Clandinin, 1967).

In India, the market price of tilapia is less than that of other freshwater fishes such as carps and murrels. Sustainable production of tilapia is possible only if farmers get more profit. The costs of pelleted feeds available in the market need to be reduced to achieve a good profit. The present study focused on replacing relatively costly SBM with cost effiective RSM. So far no work has been carried out on the nutritional aspects of GIFT tilapia cultured in cages in India. In this context, the present study was aimed to replace SBM with RSM to develop cost efficient feed for cage reared GIFT tilapia.

\section{Materials and methods}

GIFT tilapia juveniles were procured from the State Fisheries Department, Krishnagiri, Tamil Nadu, India. Before the initiation of the feeding trial, fish fingerlings were acclimated in GI framed cages $\left(6 \times 6 \times 4 \mathrm{~m}^{3}\right.$, having 1441 capacity each) for 2 weeks by feeding a commercial diet $(11.5 \%$ moisture, $32 \%$ crude protein, $5 \%$ crude lipid and $4 \%$ crude fibre). Average water temperature recorded during the acclimation period was $25.5 \pm 1.15^{\circ} \mathrm{C}$.

\section{Preparation of experimental diet}

RSM for the experiments was procured from Mahendra Feeds Pvt. Ltd., Namakkal, Tamil Nadu, India. The meal was finely pulverised using the pulveriser available at Directorate of Incubation and Vocational Training in Aquaculture, Muttukadu, Tamil Nadu and passed through $80 \mu$ mesh sized sieve. The control diet (0RSM) was formulated without addition of RSM, and four treatment diets were formulated with inclusion of RSM to replace SBM at 25, 50, 75 and $100 \%$ and designated as diet 25RSM, 50RSM, 75RSM and 100RSM, respectively. The amino acid profiles of all the formulated feeds were estimated and feeds were supplemented with limiting amino acids (lysine and methionine) to balance the required level for Nile tilapia recommended by NRC (2011). The major feed ingredients were sieved through $350 \mu \mathrm{m}$ die, homogeneously mixed and then extruded in an extruder (Unitech, New Delhi, India) through 2 $\mathrm{mm}$ die. The resultant floating pellets were dried and stored in air-tight packets. Proximate and amino acid composition of feed ingredients are given in Table 1. Composition of experimental diets and amino acid content of formulated diets are given in Table 2 and 3 respectvely.

\section{Experimental design for feeding trial}

Experiment was conducted in $1 \mathrm{~m}^{3}(1 \mathrm{~m} \times 1 \mathrm{~m} \times 1 \mathrm{~m})$ sized cages installed in the Poondi Reservoir, Thiruvallur
District. The high density poly-ethylene (HDPE) ropes and wooden frames were used to maintain the square shaped nylon meshed cages. Ten cages were used for the experiment. The stocking density was 50 nos. of juvenile GIFT tilapia per cage with a mean weight of $20.38 \pm 0.07 \mathrm{~g}$. Feeding trial was conducted with five diets, viz., 0RSM, 25RSM, 50RSM, 75 RSM and 100RSM. Each diet was fed to two replicate fish cages. The GIFT tilapia juveniles were fed thrice a day at 8.00, 12.00 and $16.00 \mathrm{hrs}$. Feeding was done as per NFDB (2016) for 60 days. The fishes were weighed every fortnight and the amount of feed adjusted accordingly.

\section{Water quality analysis}

The samples for water quality parameters were taken at fortnightly intervals between 10.00 to 10.30 hrs. Temperature, dissolved oxygen, hardness, alkalinity, ammonia, nitrite and nitrate were recorded (APHA, 1980). $\mathrm{pH}$ and dissolved oxygen levels were measured using pH meter (1100, EUTECH-Instruments, Singapore) and DO meter (HANNA, Taiwan) respectively.

\section{Fish growth assessment}

At the beginning and end of the feeding trial (60 days), fish were weighed after 1 day of feed deprivation. Feed conversion ratio (FCR), specific growth rate (SGR) and percentage survival rate were calculated as per standard procedures and formulae:

\begin{tabular}{|c|c|}
\hline $\begin{array}{l}\text { Mean feed intake } \\
(\mathrm{MFI})(\mathrm{g})\end{array}$ & $\begin{aligned}= & \text { Total feed consumed }(\mathrm{g}) /[\text { Initial } \\
& \text { no.of animals }+ \text { Final no. of animals } / 2]\end{aligned}$ \\
\hline $\begin{array}{l}\text { Mean weight gain } \\
\text { (MWG) (g) }\end{array}$ & $\begin{array}{l}=\text { Final body weight }- \text { Initial } \\
\text { body weight }\end{array}$ \\
\hline $\begin{array}{l}\text { Percentage weight } \\
\text { gain }(\mathrm{PWG})(\%)\end{array}$ & $\begin{aligned}= & {[\text { (Final body weight }- \text { Initial body }} \\
& \text { /Initial body weight }] \text { X100 }\end{aligned}$ \\
\hline $\begin{array}{l}\text { Food conversion } \\
\text { ratio (FCR) }\end{array}$ & $\begin{aligned}= & {[\text { Wet weight gain }(\mathrm{g}) / \text { Total feed }} \\
& \text { consumed }(\mathrm{g})] \text { X100 }\end{aligned}$ \\
\hline $\begin{array}{l}\text { Food } \\
\text { efficie }\end{array}$ & $\begin{aligned}= & {[\text { Wet weight gain }(\mathrm{g}) / \text { Total feed }} \\
& \text { consumed }(\mathrm{g})] \mathrm{X} 100\end{aligned}$ \\
\hline $\begin{array}{l}\text { Specific growth } \\
\text { rate (SGR) }(\%)\end{array}$ & $\begin{aligned}= & {[(\ln \text { final mean weight }-\ln \text { initial }} \\
& \text { mean weight }) / \text { No. of days }] \times 100\end{aligned}$ \\
\hline $\begin{array}{l}\text { Protein efficiency } \\
\text { ratio (PER) }\end{array}$ & $=$ Wet wet gain $(\mathrm{g}) /$ Protein ingested $(\mathrm{g})$ \\
\hline $\begin{array}{l}\text { Average daily } \\
\text { growth (ADG) }\end{array}$ & $\begin{array}{l}\text { Mean final weight }- \text { Mean initial } \\
\text { weight } / \text { Days of culture }\end{array}$ \\
\hline $\begin{array}{l}\text { Percentage of } \\
\text { survival }(\%)\end{array}$ & $=\begin{array}{l}\text { (No. of animals survived at the end } \\
\text { of experiment/No. of animals } \\
\text { stocked at the start of experiment) } \times 100\end{array}$ \\
\hline $\begin{array}{l}\text { Hepatosomatic } \\
\text { Index (HSI) }\end{array}$ & $\begin{aligned}= & {[\text { Weight of liver/Weight of the fish }] } \\
& \text { x100 }\end{aligned}$ \\
\hline
\end{tabular}




\section{Proximate analysis}

At the beginning of the feeding trail, 10 fishes were sacrificed for whole body proximate analysis. At the end of the experiment, 6 fish from each cage were sacrificed for whole body proximate analysis and for determination hepatosomatic index (HSI). The moisture, crude protein, lipid, ash, fiber, nitrogen free extract (NFE) and gross energy of experimental diets and whole body of the fishes were analysed according to standard procedure (AOAC, 1995). Moisture was determined by oven drying at 105$110^{\circ} \mathrm{C}$ for $6 \mathrm{~h}$ and protein by Micro Kjeldhal method after acid digestion. Lipid was determined by Soxhlet method by extracting in ether which is continuously volatilised at $60-80^{\circ} \mathrm{C}$. Crude fiber was estimated by dried fat free residues after digestion with dilute acid $(0.255 \mathrm{~N})$ and alkali $(0.313 \mathrm{~N})$. Ash was determined by ignition at $600^{\circ} \mathrm{C}$ for $6 \mathrm{~h}$ in a muffle furnace. Gross energy (GE) was estimated using Digital Bomb Calorimeter (Model No. RSB, Rajdhani Scientific Inst. Co. New Delhi, India).

\section{Statistical analysis}

Oneway analysis of variance (ANOVA) was carried out to find out significant difference among the treatments. Tukey's multiple range tests was used to compare between treatment means. The data were statistically analysed by SPSS 20.0 for windows (SPSS Inc., Chicago, IL, USA).

\section{Results}

Growth performances and feeding efficiency

GIFT tilapia fed with 75RSM diet recorded maximum weight gain (120.45 g) compared to fish fed control and other treatment diets. However, it was not significantly different $(\mathrm{p}>0.05)$ from 0RSM, 50RSM and 100RSM fed groups of GIFT tilapia. Maximum SGR (3.22) attained by GIFT tilapia fed with 75RSM diet was significantly different $(p<0.05)$ from all other groups of fishes (Table 4$)$.

GIFT tilapia fed with 75RSM diet showed best FCR (1.03) and poorest FCR was recorded in fish fed with 25RSM (1.29), which was not significantly different ( $>$ $>0.05$ ) from the FCR recorded in fish fed with 0RSM, 50RSM and 100RSM diets. The maximum PER was recorded in fish fed with 75RSM diet (3.23), although it was not significantly $(p>0.05)$ different from the PER attained by the fish fed with 0RSM, 50RSM and 100RSM diets. The lowest PER was found in the fishes fed with 25RSM (2.56), which was not significantly different $(p>0.05)$ from PER recorded in fish fed 0RSM, 50RSM and 100RSM.

Average daily growth (ADG) of fish fed 75RSM $(2.00 \mathrm{~g})$, was significantly $(\mathrm{p}<0.05)$ different from control and all other treatments. Minimum ADG (1.64) was recorded in the fishes fed with 25RSM diet, which was not significantly different $(\mathrm{p}>0.05)$ from the groups of fish fed with 0RSM, 50RSM and 100RSM diets. Mean feed intake was noted highest $(139.83 \mathrm{~g})$ in the groups of fishes fed with 100RSM. However, it was not significantly different ( $>0.05$ ) from mean feed intake recorded in the groups of fishes fed with all other RSM incorporated diets (25RSM, 50RSM and 75RSM) and control diet (0RSM).

Highest HSI was recorded in the group of fishes fed with diet 50RSM (2.56), though it was not significantly different $(p>0.05)$ from the HSI recorded in the group of fishes fed with diets 0RSM and 75RSM. Though least HSI (2.22) was recorded in 25RSM diet fed GIFT tilapia, it was

Table 1. Proximate and amino acid composition of feed ingredients ( $\%$ of dry weight)

\begin{tabular}{|c|c|c|c|c|c|}
\hline Ingredients & Fish meal & Soybean meal & Rapeseed meal & Maize flour & Wheat flour \\
\hline Moisture & 8.96 & 7.63 & 10.04 & 9.8 & 11.74 \\
\hline Protein & 63.28 & 48.7 & 37.9 & 8.29 & 10.05 \\
\hline Lipid & 6.89 & 1.99 & 2.1 & 4.37 & 1.56 \\
\hline Ash & 20.18 & 7.75 & 6.47 & 1.89 & 1.69 \\
\hline Fibre & 3.7 & 7.06 & 11.15 & 2.78 & 1.6 \\
\hline $\begin{array}{l}\text { Gross Energy } \\
\left(\mathrm{Kcal} \mathrm{kg}^{-1}\right)\end{array}$ & 4254 & 4297 & 4079 & 3907 & 3714 \\
\hline \multicolumn{6}{|c|}{ Amino acid content of the ingredients ( $\%$ of dry matter) } \\
\hline Arginine & 6.2 & 7.4 & 6.0 & 4.5 & 4.7 \\
\hline Histidine & 2.4 & 2.6 & 2.6 & 2.8 & 2.3 \\
\hline Isoleucine & 4.2 & 4.6 & 4.0 & 3.5 & 3.4 \\
\hline Leucine & 7.2 & 7.5 & 6.8 & 12.0 & 6.5 \\
\hline Lysine & 7.5 & 6.1 & 5.5 & 3.1 & 2.9 \\
\hline Methionine & 2.7 & 1.4 & 2.0 & 2.1 & 1.6 \\
\hline Phenylalanine & 3.9 & 5.0 & 3.9 & 4.8 & 4.5 \\
\hline Threonine & 4.1 & 3.9 & 4.3 & 3.6 & 2.9 \\
\hline Tryptophan & 1.0 & 1.3 & 1.2 & 0.7 & 1.2 \\
\hline Valine & 4.9 & 4.8 & 5.1 & 4.8 & 4.3 \\
\hline
\end{tabular}


Table 2. Composition of experimental diets ( $\%$ of dry weight)

\begin{tabular}{|c|c|c|c|c|c|}
\hline \multirow[t]{2}{*}{ Ingredients } & \multicolumn{5}{|c|}{ Formulated feeds } \\
\hline & 0RSM & 25RSM & 50RSM & 75RSM & 100RSM \\
\hline Soy bean meal ${ }^{1}$ & 24.64 & 18.48 & 12.32 & 6.16 & 0 \\
\hline Fish meal $^{1}$ & 21.33 & 21.8 & 22.5 & 22.8 & 23.0 \\
\hline Rapeseed meal ${ }^{2}$ & 0 & 7.9 & 15.83 & 23.74 & 31.66 \\
\hline Maize flour ${ }^{1}$ & 33.15 & 34.13 & 34.33 & 34.46 & 34.54 \\
\hline Wheat flour ${ }^{1}$ & 14.0 & 10.88 & 8.35 & 6.3 & 4.34 \\
\hline Palm oil ${ }^{1}$ & 3.16 & 3.13 & 3.08 & 3.05 & 3.02 \\
\hline Vitamin/mineral mix ${ }^{3}$ & 1.88 & 1.88 & 1.88 & 1.88 & 1.88 \\
\hline Vitamin $C^{3}$ & 0.12 & 0.12 & 0.12 & 0.12 & 0.12 \\
\hline L-Lysine ${ }^{4}$ & 0.44 & 0.44 & 0.39 & 0.36 & 0.35 \\
\hline DL-Methionine ${ }^{5}$ & 1.28 & 1.24 & 1.2 & 1.13 & 1.09 \\
\hline Total & 100 & 100 & 100 & 100 & 100 \\
\hline \multicolumn{6}{|c|}{ Proximate composition of feeds } \\
\hline Moisture & 9.7 & 9.65 & 9.19 & 9.82 & 9.56 \\
\hline Protein & 32.7 & 32.36 & 32.32 & 31.41 & 30.52 \\
\hline Lipid & 6.56 & 6.94 & 6.4 & 6.86 & 7.1 \\
\hline Ash & 8.39 & 8.58 & 8.99 & 9.37 & 9.63 \\
\hline Fibre & 1.25 & 1.64 & 1.76 & 1.57 & 2.06 \\
\hline Gross energy $\left(\mathrm{Kcal} \mathrm{kg}^{-1}\right)$ & 4173 & 4183 & 4155 & 4125 & 4123 \\
\hline
\end{tabular}

${ }^{1}$ Hakita Feeds Pvt. Ltd., Pondicherry, India; ${ }^{2}$ Mahindra Feeds Pvt. Ltd., Namakkal, Tamil Nadu, India; ${ }^{3}$ Anicare, Chennai, India

${ }^{4}$ Ajinomoto Heartland, Inc., Chicago; ${ }^{5}$ Evonik AG, Germany

Table 3. Calculated dietary amino acid content of formulated feeds used in the experiment

\begin{tabular}{lllllll}
\hline $\begin{array}{l}\text { Essential } \\
\text { amino acids }\end{array}$ & $\begin{array}{l}\text { Requirement } \\
\text { of Nile Tilapia }^{1}\end{array}$ & \multicolumn{5}{c}{ \% Dietary protein } \\
\cline { 5 - 7 } & & 0RSM & 25RSM & $50 R S M$ & 75RSM & 100RSM \\
\hline Arginine & 4.20 & 5.12 & 5.21 & 5.26 & 5.33 & 5.39 \\
Histidine & 1.72 & 2.53 & 2.46 & 2.41 & 2.37 & 2.33 \\
Isoleucine & 3.11 & 3.58 & 3.61 & 3.65 & 3.68 & 3.74 \\
Leucine & 3.39 & 8.25 & 8.34 & 8.41 & 8.48 & 8.56 \\
Lysine & 5.12 & $5.12\left(4.68^{\left.\mathrm{a}+0.44^{\mathrm{b}}\right)}\right.$ & $5.12\left(4.68^{\mathrm{a}}+0.44^{\mathrm{b}}\right)$ & $5.12\left(4.73^{\mathrm{a}}+0.39^{\mathrm{b}}\right)$ & $5.12\left(4.76^{\mathrm{a}}+0.36^{\mathrm{b}}\right)$ & $5.12\left(4.77^{\mathrm{a}}+0.35^{\mathrm{b}}\right)$ \\
Methionine & 3.21 & $3.21\left(1.93^{\mathrm{c}}+1.28^{\mathrm{d}}\right)$ & $3.21\left(1.97^{\mathrm{c}}+1.24^{\mathrm{d}}\right)$ & $3.21\left(2.01^{\mathrm{c}}+1.20^{\mathrm{d}}\right)$ & $3.21\left(2.08^{\mathrm{c}}+1.13^{\mathrm{d}}\right)$ & $3.21\left(2.12+1.09^{\mathrm{d}}\right)$ \\
Phenylalanine & 5.54 & 4.12 & 4.15 & 4.18 & 4.22 & 4.25 \\
Threonine & 3.75 & 3.42 & 3.47 & 3.52 & 3.57 & 3.62 \\
Tryptophan & 1.00 & 0.98 & 0.96 & 0.93 & 0.91 & 0.89 \\
Valine & 2.80 & 4.81 & 4.86 & 4.92 & 4.99 & 5.04
\end{tabular}

${ }^{1}$ Santiago and Lovell (1988), Amino acid requirements for growth of Nile tilapia; ${ }^{\text {a }}$ Calculated lysine amount in the experimental feed without

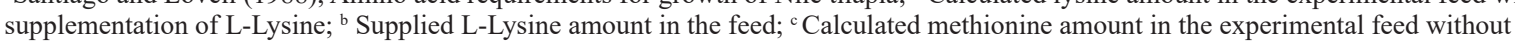
supplementation of DL-Methionine; ${ }^{\mathrm{d}}$ Supplied DL-Methionine amount in the feed

not significantly $(\mathrm{p}>0.05)$ different from the HSI values recorded from the groups of fishes fed with diets ORSM, 75RSM and 100RSM. Survival showed no significant difference among the diets and it ranged from 98 to $100 \%$ among the treatments.

\section{Whole body chemical composition}

At the end of the experiment, it was observed that GIFT tilapia fed with control and RSM incorporated diets showed no significant difference in moisture, protein, lipid and ash content in whole body analysis (Table 5). Similarly, no significant difference $(\mathrm{p}>0.05)$ was observed in the initial and final proximate composition.

\section{Discussion}

In the present investigation, the growth experiment was conducted using RSM protein to replace SBM protein gradually, in the diets of GIFT tilapia. Similar kind of experiment was conducted by Davies et al. (1990), Lim and Klesius (1998) and Plaipetch and Yakupitiyage (2014) by using RSM protein to replace SBM protein in the diets of $O$. niloticus. Many researchers have utilised RSM as an alternative plant protein ingredient in fishes and have found different results with regard to growth performances and the feed utilisation (Yurkowski et al., 1978; Hardy and Sullivan, 1983; Hilton and Slinger, 1986; Leatherland 
Table 4. Growth performance and feed utilization of GIFT tilapia fed experimented diets

\begin{tabular}{|c|c|c|c|c|c|c|c|c|c|c|c|c|}
\hline Treat & $\begin{array}{l}\text { Mean initia } \\
\text { weight }(\mathrm{g})\end{array}$ & $\begin{array}{l}\text { Mean final } \\
\text { weight }(\mathrm{g})\end{array}$ & $\begin{array}{l}\text { Mean weight } \\
\text { gain }(\mathrm{g})\end{array}$ & PW & SGR & PER & FCR & FCE & $\begin{array}{l}\text { ADG } \\
(\mathrm{g})\end{array}$ & $\begin{array}{l}\mathrm{Me} \\
\text { inta }\end{array}$ & HSI & $\begin{array}{l}\text { Survival } \\
(\%)\end{array}$ \\
\hline SM & & & & & $2 \mathrm{~b} \pm 5.21$ & & & & & & & 100 \\
\hline RSM & $20.32 \pm 0.85$ & $119.02^{b} \pm 21.74$ & $98.70^{b} \pm 20.88$ & & $2.94^{b} \pm 5.39$ & $2.56 \pm 3.34$ & $1.29^{2} \pm 0.99$ & & & & $2.22^{b} \pm 0.01$ & $98 \pm 2.0288$ \\
\hline 50RSM & $20.43 \pm 0.87$ & $122.47^{\mathrm{b}} \pm 28.04$ & $102.04^{\mathrm{ab}} \pm 27.16$ & $499.4^{\mathrm{ab}} \pm 3$ & $2.98^{\mathrm{b}}=$ & $2.85^{\mathrm{ab}} \pm 4.8$ & $1.16^{\mathrm{ab}} \pm 0.69$ & $85.74^{\mathrm{ab} \pm}$ & 1.70 & .19 & 2.56 & 0165 \\
\hline 75RSM & $20.38 \pm 0.9$ & $140.83^{\mathrm{a}} \pm 34.37$ & $120.45^{\mathrm{a}} \pm 33.47$ & $590.89 \pm 36.93$ & $3.22^{2}$ & $3.23^{\mathrm{a}} \pm 5.58$ & $1.03^{b} \pm 0.59$ & $96.93^{\mathrm{a}} \pm 1.67$ & $2.00^{a} \pm 0.55$ & $132.67^{a} \pm 0.22$ & $2.42^{\mathrm{ab}} \pm 0.15$ & 100 \\
\hline 100RSM & $20.35 \pm 0.9$ & $140.83^{a} \pm 34.37$ & $104.33^{\mathrm{ab}} \pm 30.89$ & $512.60^{\mathrm{bc}} \pm 34.04$ & $3.02^{\mathrm{b}} \pm 5.92$ & $2.68^{\mathrm{ab}} \pm 3.77$ & $1.24^{\mathrm{ab}} \pm 0.88$ & $80.43^{\mathrm{ab}} \pm 1.13$ & $1.73^{b} \pm 0.51$ & $139.83^{a} \pm 0.28$ & $2.24^{b} \pm 0.06$ & 100 \\
\hline Value & 0.861 & 0.001 & 0.001 & 0.001 & 0.001 & 0.043 & 0.001 & 0.001 & 0.001 & 0.001 & 0.046 & 0.001 \\
\hline
\end{tabular}

Table 5. Initial and final whole body proximate composition of experimental fishes (\% of wet weight)

\begin{tabular}{lllll}
\hline Treatment & Moisture & Protein & Lipid & Ash \\
\hline Initial & $71.38 \pm 0.15$ & $16.74 \pm 0.08$ & $6.46 \pm 0.04$ & $4.41 \pm 0.02$ \\
0RSM & $72.41 \pm 0.14$ & $16.46 \pm 0.07$ & $5.34 \pm 0.05$ & $4.23 \pm 0.03$ \\
25RSM & $72.33 \pm 0.16$ & $16.66 \pm 0.09$ & $5.41 \pm 0.03$ & $4.59 \pm 0.04$ \\
50 RSM & $72.37 \pm 0.17$ & $16.28 \pm 0.06$ & $5.79 \pm 0.05$ & $4.47 \pm 0.03$ \\
75 RSM & $72.53 \pm 0.14$ & $16.52 \pm 0.07$ & $5.28 \pm 0.04$ & $4.22 \pm 0.04$ \\
100RSM & $72.44 \pm 0.16$ & $16.46 \pm 0.08$ & $5.83 \pm 0.05$ & $4.64 \pm 0.02$ \\
pValue & 0.515 & 0.843 & 0.629 & 0.889 \\
\hline
\end{tabular}

et al., 1987; Davies et al., 1990; Gomes et al., 1993; Higgs et al., 1995; Lim et al., 1997; Webster et al., 1997; Yue and Zhou, 2008).

RSM as a potential substitute for fish meal has been the subject of numerous studies with rainbow trout (Yurkowski et al., 1978; Hilton and Slinger, 1986; McCurdy and March, 1992; Gomes et al., 1993), chinook salmon (Higgs et al., 1982), tilapia (Oreochromis mossambicus) (Jackson et al., 1982; Davies et al., 1990), channel catfish (Webster et al., 1997) and Pacific white shrimp (Penaeus vannamei) (Lim et al., 1997). Among the RSM included diets, the best FCR was observed in 75RSM diet fed fishes (1.03), which was not significantly different from 0RSM, 25RSM and 100RSM. Similar results were recorded in replacing SBM with plant ingredients (Dorsa et al., 1982; Robinson and Daniels, 1987; Lim et al., 1998; Barros et al., 2002; Zhou and Yue, 2010; El-Saidy and Saad, 2011; Plaipetch and Yakupitiyagez, 2014). Davies et al. (1990) and Yue and Zhou (2008) concluded that, higher inclusion level of RSM and cottonseed meal (CSM) respectively, significantly affects FCR in fishes.

Mean weight gain (MWG) and protein efficiency ratio (PER) were observed highest in GIFT tilapia fed with 75RSM diet, though it was not significantly different from fishes fed with 50RSM and 100RSM diets. According to Plaipetch and Yakupitiyagez (2014), fermented RSM inclusion upto and over $75 \%$ of the SBM replacement level, showed reduced PER and significantly varied with control diet and lower levels of inclusion. Similarly, retarded PER was observed by Yue and Zhou (2008) in juvenile hybrid tilapia (O. niloticus x $O$. aureus) and Davies et al. (1990) in O. mossambicus. However, PER was found unaffected in higher inclusion level of plant protein in replacement of SBM (Yue and Zhou, 2008; El-Saidy and Saad, 2011). Average daily growth was observed highest in 75RSM diet, which was significantly higher than that for other diets in the present growth experiment. Plaipetch and Yakupitiyagez (2014), found no significant difference in daily weight gain among Nile tilapia fed diets with fermented RSM replacing SBM in diets, at all replacement levels.

Mean feed intake was recorded highest in 100RSM $(139.83 \mathrm{~g})$, and no significant difference was observed among other treatments. Similar results were observed for replacement of SBM with fermented RSM (Plaipetch and Yakupitiyagez, 2014), with CSM in Nile tilapia (El-Saidy and Saad, 2011) and channel catfish (Robinson and $\mathrm{Li}, 1994)$. On the contrary, Davies et al. (1990) observed declining level of feed intake with increasing level of RSM replacement in tilapia (O. mossambicus) diet.

In the present study, the survival of the GIFT tilapia was not significantly $(p>0.05)$ affected by different levels of RSM inclusion. Similar trends of experimental fish survivability was observed in replacement studies of SBM with CSM in channel catfish (Robinson, 1991; Barros et al., 2002), juvenile hybrid tilapia (Yue and Zhou, 2008) and mono sex male Nile tilapia (El-Saidy and Saad, 2011).

In the present study, diet with $75 \%$ RSM protein replacement upon SBM protein showed significantly higher MWG and PER than other diets including control diet, with good FCR of 1.03 . However previous studies have concluded that, RSM can be incorporated in the 
diets of hybrid tilapia upto a level of $19.02 \%$, which can replace $30 \%$ protein of SBM, without significant negative effects on growth performance and feed utilisation (Zhou and Yue, 2010). Weight gain, SGR and PER of juvenile hybrid tilapia were significantly retarded at replacement levels exceeding 30\% of SBM with RSM. Davies et al. (1990) reported that only 15\% RSM could effectively replace SBM in tilapia (O. mossambicus) diets. Similar results were also observed in rainbow trout (Yurkowski et al., 1978; Hardy and Sullivan, 1983; Hilton and Slinger, 1986; Leatherland et al., 1987; Gomes et al., 1993). Jackson et al. (1982) found decrease in growth rates in O. mossambicus when $75 \%$ FM protein was replaced by RSM and indicated that it may have been due to the toxic effects of glucosinolates.

Inadequate essential amino acids (especially, lysine and methionine) could be the main reason that causes negative growth performances in fish fed higher RSM included diets (Enami, 2011). In this present study, limiting amino acids viz., methionine and lysine were considered during the formulation of experimental diets. Tacon and Metian (2008) reported that the growth performance of Nile tilapia was improved when $0.8 \%$ DL-methionine was supplemented to a diet in which $75 \%$ of fish meal was replaced by SBM. These results are in agreement with the present study, which reported that weight gain of juvenile GIFT tilapia increased significantly as methionine levels increased by supplementation of crystalline methionine, indicating that juvenile GIFT tilapia could use crystalline methionine efficiently when supplemented in practical diets. The experiment pertaining to the evaluation of alternative plant protein source, concluded that, RSM can completely $(100 \%)$ replace SBM protein in the diets of GIFT tilapia reared in cage installed in reservoir. RSM could be incorporated at a level of $31.66 \%$ in diets of GIFT tilapia which corresponds to a complete exclusion of SBM at a level of $24.64 \%$ in the control diet without compromising growth, FCR and whole body composition.

\section{Acknowledgements}

The authors sincerely thank National Agriculture Development Programme (NADP), India and Tamil Nadu Dr. J. Jayalalithaa Fisheries University (TNJFU), Nagapattinam, Tamil Nadu, India for the funding support to carry out this study.

\section{References}

AOAC 1995. Official methods of analysis, $13^{\text {th }}$ edn. Association of Official Analytical Chemists, Washington D. C., USA

APHA 1980. Standard methods for the examination of water and waste water, $16^{\text {th }}$ edn. American Public Health Association, Washington D. C., USA.

Barros, M. M., Lim, C. and Klesius, P. H. 2002. Effect of soybean meal replacement by cottonseed meal and iron supplementation on growth, immune response and resistance of channel catfish (Ictalurus puctatus) to Edwardsiella ictaluri challenge. Aquaculture, 207 (3-4): 263-279. DOI: 10.1016/S0044-8486(01)00740-2.

Clandinin, D. 1967. Nutrient composition of expeller, prepresssolvent, and solvent processed rapeseed meals. Poult. Sci., 46 (6): 1596-1597. DOI:10.3382/ps.0461596.

Davies, S. J., McConnell, S. and Bateson, R. I. 1990. Potential of rapeseed meal as an alternative protein source in complete diets for tilapia (Oreochromis mossambicus). Aquaculture, 87 (2): 145-154. https://doi.org/10.1016/00448486(90)90271-N.

Dey, M. M. 2000. The impact of genetically improved farmed Nile tilapia in Asia. Aquac. Econ.Manage., 4 (1-2): 107-124. https://doi.org/10.1080/13657300009380263.

Dorsa, W. J., Robinette, H. R., Robinson, E. H. and Poe, W. 1982. Effects of dietary cottonseed meal and gossypol on growth of young channel catfish. Trans. Am. Fish. Soc., 111 (5): 651-655.

El-Saidy, D. M. and Saad, A. S. 2011. Effects of partial and complete replacement of soybean meal with cottonseed meal on growth, feed utilization and haematological indexes for mono-sex male Nile tilapia, Oreochromis niloticus (L.) fingerlings. Aquac. Res., 42 (3): 351-359. https://doi.org/10.1111/j.1365-2109.2010.02629.x.

Enami, H. 2011. A review of using canola/rapeseed meal in aquaculture feeding. J. Fish.Aquat.Sci., 6 (1): 22-36.

FAO 2018. The State of world fisheries and aquaculture 2016: Contributing to food security and nutrition for all, Food and Agriculture Organization of the United Nations, Rome, Italy, $200 \mathrm{pp}$.

Gomes, E. F., Corraze, G. and Kaushik, S. 1993. Effects of dietary incorporation of a co-extruded plant protein (rapeseed and peas) on growth, nutrient utilization and muscle fatty acid composition of rainbow trout (Oncorhynchus mykiss). Aquaculture, 113 (4): 339-353. http://dx.doi. org/10.1016/0044-8486(93)90404-M.

Hardy, R. W. and Sullivan, C. V. 1983. Canola meal in rainbow trout (Salmo gairdneri) production diets. Can. J. Fish. Aquat. Sci., 40 (3): 281-286.

Hertrampf, J. W. and Piedad-Pascual, F. 2012. Handbook on ingredients for aquaculture feeds, Springer Science and Business Media, Berlin, Germany.

Higgs, D. A., McBride, J. R., Markert, J. R., Dosanjh, B. S., Plotnikoff, M. D. and Clarke, W. C. 1982. Evaluation of Tower and Candle rapeseed (canola) meal and Bronowski rapeseed protein concentrate as protein supplements in practical dry diets for juvenile chinook salmon (Oncorhynchus tshawytscha). Aquaculture, 29 (1-2): 1-31. DOI: 10.1016/0044-8486(82)90030-8.

Higgs, D., Dosanjh, B., Prendergast, A., Beames, R., Hardy, R., Riley, W. and Deacon, G. 1995. Use of rapeseed/canola 
protein products in finfish diets. In: Lim, C. E. and Sessa, D. J. (Eds.), Nutrition and utilization technology in aquaculture, AOCS Press, Champaign, p. 130-156.

Hilton, J. and Slinger, S. 1986. Digestibility and utilization of canola meal in practical-type diets for rainbow trout (Salmo gairdneri). Can. J. Fish. Aquat. Sci., 43 (6): 1149-1155. DOI: 10.1139/f86-143.

Jackson, A., Capper, B. and Matty, A. 1982. Evaluation of some plant proteins in complete diets for the tilapia, Sarotherodon mossambicus. Aquaculture, 27 (2): 97-109.

Khaw, H. 2010. Genetic analysis of the GIFT strain (Nile Tilapia, Oreochromis niloticus) in Malaysia. Age, 27502 (211): 91.2.

Leatherland, J., Hilton, J. and Slinger, S. 1987. Effects of thyroid hormone supplementation of canola meal-based diets on growth, and interrenal and thyroid gland physiology of rainbow trout (Salmo gairdneri). Fish Physiol. Biochem., 3 (2): 73-82. DOI: 10.1007/BF02183001.

Lim, C., Beames, R., Eales, J., Prendergast, A., McLeese, J., Shearer, K. and Higgs, D. 1997. Nutritive values of low and high fibre canola meals for shrimp (Penaeus vannamei). Aquac. Nutr., 3 (4): 269-279. https://doi.org/10.1046/j.13652095.1997.00048.x.

Lim, C., Klesius, P. and Higgs, D. 1998. Substitution of canola meal for soybean meal in diets for channel catfish, Ictalurus punctatus. J. World Aquac.Soc., 29 (2): 161-168. https:// doi.org/10.1111/j.1749-7345.1998.tb00975.x.

McCurdy, S. and March, B. 1992. Processing of canola meal for incorporation in trout and salmon diets. J. Am. Oil Chem. Soc., 69 (3): 213-220.

NFDB 2016. Guidelines for cage culture in inland open water bodies of India. National Fisheries Development Board, Hyderabad, India, $9 \mathrm{pp}$.

Ng, W. K. and Hanim, R. 2007. Performance of genetically improved Nile tilapia compared with red hybrid tilapia fed diets containing two protein levels. Aquac. Res., 38 (9): 965-972. https://doi.org/10.1111/j.1365-2109.2007.01758.x.

Nguyen, N. H., Khaw, H. L., Ponzoni, R. W., Hamzah, A. and Kamaruzzaman, N. 2007. Can sexual dimorphism and body shape be altered in Nile tilapia (Oreochromis niloticus) by genetic means? Aquaculture, 272: 38-46.

NRC 2011. Nutrient requirements of fish and shrimp. National Research Council, Washington, DC, USA.

Plaipetch, P. and Yakupitiyage, A. 2014. Effect of replacing soybean meal with yeast-fermented canola meal on growth and nutrient retention of Nile tilapia, Oreochromis niloticus (Linnaeus 1758). Aquac. Res.,45 (11):17441753. https://doi.org/10.1111/are.12119.

Ponzoni, R. W., Hamzah, A., Tan, S. and Kamaruzzaman, N. 2005. Genetic parameters and response to selection for live weight in the GIFT strain of Nile tilapia (Oreochromis niloticus). Aquaculture, 247 (1-4): 203-210.
Ponzoni, R., Nguyen, N., Khaw, H., Kamaruzzaman, N., Hamzah, A., Bakar, K. A. and Yee, H. 2008. Genetic improvement of Nile tilapia (Oreochromis niloticus) - present and future. In: Elghobashy, H., Fitzsimmons, K., Diab, A. S. (Eds.), Proceedings of $8^{\text {th }}$ International Symposium on Tilapia in aquaculture, vol. 1, 12-14 October 2008, Cairo, Egypt, p. 33-52.

Robinson, E. H. and Daniels, W. H. 1987. Substitution of soybean meal with cottonseed meal in pond feeds for channel catfish reared at low densities. J. World Aquac.Soc., 18 (2): 101-106.https://doi.org/10.1111/j.1749-7345.1987. tb00424.x.

Robinson, E. H. and Li, M. H. 1994. Use of plant proteins in catfish feeds: replacement of soybean meal with cottonseed meal and replacement of fish meal with soybean meal and cottonseed meal. J. World Aquac. Soc., 25 (2): 271-276. https://doi.org/10.1111/j.1749-7345.1994.tb00190.x.

Robinson, E. H. 1991. Improvement of cottonseed meal protein with supplemental lysine in feeds for channel catfish. J. Appl. Aquac., 1 (2): 1-14. DOI: 10.1300/J028v01n02-01.

Santiago, C. B. and Lovell, R. T. 1988. Amino acid requirements for growth of Nile tilapia. J. Nutr. 118 (12): 1540-1546. DOI:10.1093/jn/118.12.1540.

Tacon, A. G. and Metian, M. 2008. Global overview on the use of fish meal and fish oil in industrially compounded aquafeeds: Trends and future prospects. Aquaculture, 285 (1-4): 146-158. https://doi.org/10.1016/j.aquaculture.2008.08.015.

Takagi, S., Hosokawa, H., Shimeno, S. and Ukawa, M. 2000. Utilization of poultry byproduct meal in a diet for red sea bream, Pagrus major. Nippotn Suisan Gakkaishi, 66: 428-438. doi:org/10.2331/suisan.66.428.

Takagi, S., Shimeno, S., Hosokawa, H. and Ukawa, M. 2000. Replacement of fish meal by combined inclusion of alternative protein sources in a diet for yearling red sea bream, Pagrus major. Aquac. Sci., 48 (3): 545-552.

Webster, C. D., Tiu, L. G., Tidwell, J. H. and Grizzle, J. M. 1997. Growth and body composition of channel catfish (Ictalurus punctatus) fed diets containing various percentages of canola meal. Aquaculture, 150 (1-2): 103-112. https://doi. org/10.1016/S0044-8486(96)01471-8.

Yue, Y. R. and Zhou, Q. C. 2008. Effect of replacing soybean meal with cottonseed meal on growth, feed utilization, and hematological indexes for juvenile hybrid tilapia, Oreochromis niloticus $\times$ O. aureus. Aquaculture, 284 (1-4): 185-189.

Yurkowski, M., Bailey, J., Evans, R., Tabachek, J. A. L., Ayles, G. B. and Eales, J. 1978. Acceptability of rapeseed proteins in diets of rainbow trout (Salmo gairdneri). J. Fish. Board Can., 35 (7): 951-962.

Zhou, Q. C. and Yue, Y. R. 2010. Effect of replacing soybean meal with canola meal on growth, feed utilization and haematological indices of juvenile hybrid tilapia, Oreochromis niloticus $\times$ Oreochromis aureus. Aquac. Res., 41(7): 982-990.

Date of Receipt : 21.04 .2019

Date of Acceptance : 22.08 .2019 